Отримано: 31 серпня 2018 р.

Прорецензовано: 12 вересня 2018 р.

Прийнято до друку: 19 вересня 2018 р.

e-mail: Julia.kharchuk@oa.edu.ua
Харчук Ю. Ю. Взаємозв'язок між економічною безпекою та фінансовою стійкістю закладів вищої освіти на ринку освітніх послуг україни в контексті їх обліково-аналітичного забезпечення. Наукові записки Національного університету «Острозька академія». Серія «Економіка» : науковий журнал. Острог : Вид-во НаУОА, вересень 2018. № 10(38). C. 137-144.

DOI: $10.25264 / 2311-5149-2018-10(38)-137-144$

УДК 657.631.6: $336.61(477)$

JEL-класифікація: I 12-23; M 31; $M 41$

Харчук Юлія Юріївна,

кандидат економічних наук, дочент кафедри фінансів, обліку і аудиту, заступник декана економічного факультету з профорієнтаційної роботи, Національний університет «Острозька академія»

\title{
ВЗАЕМОЗВ'ЯЗОК МІЖ ЕКОНОМІЧНОЮ БЕЗПЕКОЮ ТА ФІНАНСОВОЮ СТІЙКІСТЮ ЗАКЛАДІВ ВИЩОЇ ОСВІТИ НА РИНКУ ОСВІТНІХ ПОСЛУГ УКРАЇНИ В КОНТЕКСТІ ЇХ ОБЛІКОВО-АНАЛІТИЧНОГО ЗАБЕЗПЕЧЕННЯ
}

У статті уточнено сутність економічної безпеки, фінансової стійкості закладів вищої освіти державної та комунальної власності в Україні в контексті їх обліково-аналітичного забезпечення. Розглянуто специффіку аналітичного обліку базових складових економічної безпеки і фінансової стійкості закладів вищої освіти України. Виявлено взаємозв'язок між рівнем економічної безпеки закладів вищої освіти та типом їхньої фінансової стійкості. Обгрунтовано вплив якості обліково-аналітичного забезпечення фінансової стійкості закладів вищої освіти на рівень їхньої економічної безпеки. Запропоновано напрями підвищення економічної безпеки та фінансової стійкості закладів вищої освіти Украӥни на основі покращення їх обліково-аналітичного забезпечення.

Ключові слова: економічна безпека, фінансова стійкість, заклади вищої освіти державної та комунальної власності, обліково-аналітичне забезпечення.

Харчук Юлия Юрьевна,

кандидат экономических наук,доцент кафедры финансов, учета и аудита, заместитель декана экономического факультета по профориентационной работе, Национальный университет «Острожская академия»

\section{ВЗАИМОСВЯЗЬ МЕЖДУ ЭКОНОМИЧЕСКОЙ БЕЗОПАСНОСТЬЮ \\ И ФИНАНСОВОЙ УСТОЙЧИВОСТЬЮ УЧРЕЖДЕНИЙ ВЫСШЕГО ОБРАЗОВАНИЯ НА РЫНКЕ ОБРАЗОВАТЕЛЬНЫХ УСЛУГ УКРАИНЫ В КОНТЕКСТЕ ИХ УЧЕТНО-АНАЛИТИЧЕСКОГО ОБЕСПЕЧЕНИЯ}

В статье уточнена сущность экономической безопасности и финансовой устойчивости учреждений высшего образования государственной и коммунальной собственности в контексте их учетно-аналитического обеспечения. Определенно специчфику аналитического учета базовых составляющих экономической безопасности и финансовой устойчивости учреждений высшего образования Украины. Обнаружена взаимосвязь между уровнем экономической безопасности учреждений выстего образования и типом их финансовой устойчивости. Обоснованно влияние качества учетно-аналитического обеспечения финансовой устойчивости учреждений выстего образования на уровень их экономической безопасности. Предложены направления повышения экономической безопасности и финансовой устойчивости учреждений высшего образования на основе улучшения их учетно-аналитического обеспечение.

Ключевые слова: экономическая безопасность, финансовая устойчивость, учреждений высшего образования государственной и коммунальной собственности, учетно-аналитическое обеспечение.

\section{Yulia Kharchuk,}

PhD in Economics, Associate Professor at the Department of Finanse, Accounting and Audit, Deputy Dean of career guidance of the Faculty of Economics of the National University of Ostroh Academy

\section{INTERCONNECTION BETWEEN ECONOMIC SECURITY AND FINANCIAL STABILITY OF INSTITUTIONS OF HIGHER EDUCATION ON THE EDUCATIONAL MARKET OF UKRAINE IN THE CONTEXT OF THEIR REGISTRATION-ANALYTICAL PROVIDING}

The article deals with the peculiarities of the development of the Ukrainian educational services market, identifies trends in reduced number of applicants in the context of the demographic crisis and increased number of those wishing to receive higher education abroad; the intensification of competition between higher education institutions for financial provision and education services users; the lack of effective links with employers as the main stakeholders of educational programs, which should take direct part in the educational process both in intellectual and financial aspects.

The author clarifies the essence of economic security and financial stability of institutions of higher education of state and communal property in Ukraine. Features of accounting and analytical support of the studied categories are considered. 
The basic components of economic security and financial stability of institutions of higher education of Ukraine are singled out and the specifics of implementation of their synthetic and analytical accounting are revealed. It has been proved that the most specific and important objects in accounting for the activities of institutions of higher education with the aim of accounting and analytical provision of their economic security and financial sustainability are revenues, expenditures (costs, expenses) and financial results. Accounting of the above-mentioned objects is even more responsible and complex in the context of accounting and analytical support and requires the most elaborate development and processing.

It is substantiated that the algorithm of formation of accounting and analytical support of the studied categories, based on their essence and main tasks, is a system of control over the availability and movement of budget funds of general and special funds of institutions of higher education, which is based on universally recognized principles, performs administrative, control and information function The relationship between the level of economic security of institutions of higher education and the type of their financial stability is revealed. The influence of accounting and analytical provision of financial stability of institutions of higher education on the level of their economic security and quality of provided educational and non-educational services are substantiated.

The directions of increase of economic safety and financial stability of institutions of higher education of Ukraine on the basis of improvement of their accounting and analytical support are offered. The necessity of rational, effective and targeted use of allocations from the State and / or local budgets is substantiated under the condition of maximum mode of saving of all possible resources; the close cooperation of higher education institutions with employers in the field of improving the quality of educational services provision, ensuring the practical component of research activities, as well as the possibilities for funding education for talented but poorly-skilled students; ensuring fair competition with institutions of higher education through transparent, targeted professional-orientation work among potential entrants, the use of the latest innovative technologies in the educational-scientific and educational process, the involvement of faculty members and students in participating in international exchange programs and grants; use of in-depth analytics on the accounts of incomes (allocations from the State and / or local budgets of Ukraine, own revenues, including through fundraising) and expenditures (costs, expenses).

Key words: economic security, financial stability, institutions of higher education of state and communal property, registration-analytical providing.

Постановка проблеми. В сучасних умовах функціонування та розвитку ринку освітніх послуг України, зокрема сфери вищої освіти, спостерігаємо тенденції, які можуть суттєво знижувати рівень економічної безпеки, фінансової стійкості закладів вищої освіти державної та комунальної власності (далі - 3ВО), особливо в контексті їх обліково-аналітичного забезпечення. Серед основних доцільно виокремити такі:

- зменшення кількості абітурієнтів, значною мірою як із високим рейтингом (за результатами 3 НО та вступних кампаній середній бал для зарахування на державну та контрактну форму навчання в багатьох 3ВО з кожним роком знижується), так і платоспроможних, які, в умовах скорочення фінансування навчальних закладів за рахунок коштів Державного та/або місцевих бюджетів, не мають можливості самостійно, вчасно та в повному обсязі сплачувати за отримання належних освітніх послуг. Крім цього, демографічна ситуація в країні підтверджує те, що навіть в умовах «заморожування» планів прийому на рівні 2015-2016 років уже два роки поспіль місць в українських 3ВО більше ніж достатньо для всіх випускників загальноосвітніх навчальних закладів;

- загострення конкуренції між 3ВО, що, насамперед, сприяє покращенню якості надання освітніх послуг і розвитку навчальних закладів, однак у багатьох випадках призводить до використання «чорних» піар технологій через значну кількість навчальних закладів, спеціальностей і спеціалізацій;

- брак дієвих зв'язків із роботодавцями, одними із основних стейкхолдерів освітніх програм, які прагнуть працевлаштовувати винятково висококваліфіковані кадри із стажем і досвідом роботи, при цьому не беручи безпосередньої участі в освітньому процесі як в інтелектуальному, так і фінансовому аспекті.

Саме ці тенденції підтверджують необхідність детального вивчення сутності й особливостей взаємозв'язку між економічною безпекою та фінансовою стійкістю ЗВО на ринку освітніх послуг України в контексті їх обліково-аналітичного забезпечення. На це орієнтують програмні документи сьогодення: Національна стратегія розвитку освіти в Україні на 2012-2021 роки [3], Стратегія реформування вищої освіти в Україні до 2020 року [4], Стратегія інноваційного розвитку України на 2010-2020 роки в умовах глобалізаційних викликів [5], Середньостроковий план пріоритетних дій уряду до 2020 року [6], Дорожна карта освітньої реформи (2015-2025) [7], Стратегія реформування системи управління державними фінансами на 2017-2020 роки [8] тощо.

Аналіз останніх досліджень і публікацій. Організаційно-облікові й фінансово-аналітичні аспекти діяльності 3ВО в Україні розглянуто в працях таких науковців: Й. Бескида, Т. Боголіб, Т. Єфименко, В. Куценко, С. Левицької, В. Сафонової, С. Свірко, І. Стеціва [9], В. Студінського, Г. Тюлєнєва [10], В. Яблонського та інших. Ресурсне забезпечення та специфіку управління 3ВО, стратегію й оцінку їхньої економічної безпеки та фінансової стійкості вивчали російські вчені: О. Арзякова, А. Беляков, Н. Кельчевська, Е. Князєв, Е. Попов та інші. Серед західних економістів, які досліджували теоретичні й практичні аспекти господарської діяльності ЗВО можна виділити Б. Джоунстона, П. Друкера, Н. Маркуччі, Е. Моргана та інших.

Водночас питання сутності економічної безпеки та фінансової стійкості 3ВО на ринку освітніх послуг України й особливостей взаємозв'язку між ними в контексті їх обліково-аналітичного забезпечення недо- 
статньо вивчені на сучасному етапі реформування вищої освіти та потребують додаткових досліджень.

Мета дослідження полягає у визначені напрямів підвищення економічної безпеки та фінансової стійкості ЗВО на ринку освітніх послуг України на основі покращення їх обліково-аналітичного забезпечення шляхом уточнення сутності досліджуваних економічних категорій і розкриття особливостей взаємозв’ язку між ними.

Виклад основного матеріалу. В умовах сучасного реформування ринку освітніх послуг України, замало лише формально забезпечити кількісні параметри освіти, хоча й це необхідно, важливо досягти високої якості, ефективності, конкурентоспроможності, відповідності національним і світовим стандартам. Це неможливо в контексті недостатнього фінансового забезпечення діяльності ЗВО, зокрема низького рівня їхньої економічної безпеки та фінансової стійкості.

Щодо визначення сутності економічних категорій «економічна безпека» та «фінансова стійкість», то доцільно зазначити, що вони є надзвичайно розповсюдженими, широко застосованими та багатозначними. Різноманітність запропонованих вітчизняними та зарубіжними науковцями науково-методичних підходів щодо трактування значення цих понять у розрізі функціонування суб'єктів господарювання підприємницької та непідприємницької діяльності ще раз підтверджує наявність неоднозначності та суперечливостей у їх тлумаченні, а саме - актуальність і своєчасність дослідження.

Вивчаючи праці зазначених вище науковців щодо сутності економічної безпеки 3ВО [9; 10], вважаємо за доцільне погодитися із думкою І. Стеціва, відповідно до якої економічну безпеку навчальних закладів слід трактувати як такий стан їхньої економіки, що дає змогу зберігати стійкість до внутрішніх та зовнішніх загроз, а також гарантує стабільне функціонування та динамічний розвиток. Проте, слід зауважити, що все це можливо забезпечити лише за умови достатньої кількості фінансових ресурсів на покриття як поточних, так і капітальних видатків ЗВО, належного рівня фінансової стійкості та якісного обліковоаналітичного забезпечення досліджуваних категорій.

Своєю чергою, під фінансовою стійкістю ЗВО слід розуміти такий стан їхніх фінансових ресурсів, що забезпечує виконання навчальними закладами завдань якісної організації навчально-наукової діяльності та формування професійної конкурентоспроможності випускників на основі повного та своєчасного фінансового забезпечення цільовими коштами попередньо затверджених видатків (витрат, затрат). Водночас отримання запланованих цільових фінансових ресурсів (бюджетних коштів за загальним і спеціальним фондами) є основою результативної господарської діяльності (зокрема, виконання цільових бюджетних програм).

Таким чином, на нашу думку, поняття «економічна безпека» 3ВО є ширшим за поняття «фінансова стійкість». Крім цього, виходячи із сутності досліджуваних економічних категорій, можна стверджувати про існування між ними тісного взаємозв'язку. Оскільки ЗВО, яким притаманний високий рівень економічної безпеки, мають абсолютний тип фінансової стійкості, займають одні з перших позицій у рейтингах навчальних закладів вищої освіти України, користуються попитом на національному та світовому ринках освітніх послуг, мають достатній рівень фінансових ресурсів для покриття не лише поточних витрат, а й фінансування бюджетів розвитку, реалізації науково-освітніх проектів, залучення викладачів світового рівня, стажування викладацько-професорського складу та студентів у провідних університетах Європи та світу, і навпаки.

Однак, розглядаючи економічну безпеку та фінансову стійкість ЗВО в контексті їх обліково-аналітичного забезпечення, слід детальніше зупинитися на сутності й особливостях цього процесу. Так, під обліково-аналітичним забезпеченням як економічної безпеки, так і фінансової стійкості ЗВО, слід розуміти реєстрацію з достатнім рівнем аналітики обліку господарських операцій, які формують доходи, видатки (витрати, затрати), фінансові результати діяльності навчальних закладів, впливаючи на результативність використання отриманих (залучених) цільових коштів; процес вивчення даних фінансової звітності установ задля оцінки їхньог фінансового стану і результатів діяльності в минулому та прогнозування рівня економічної безпеки та типу фінансової стійкості в майбутньому.

Мета обліково-аналітичного забезпечення економічної безпеки та фінансової стійкості 3 ВО полягає в отриманні оперативної й об'єктивної інформації за господарськими операціями, які формують рівень економічної безпеки та визначають тип фінансової стійкості в поточному періоді й на перспективу; оцінці досягнутих рівня економічної безпеки та типу фінансової стійкості за попередні періоди функціонування 3ВО, прогнозування досліджуваних параметрів у майбутньому, а відтак, попередження та зниження невизначеності, пов'язаної з прийняттям управлінських рішень щодо раціонального використання фінансових ресурсів [11; 12] і підвищення конкурентоспроможності на ринку освітніх послуг України та світу.

Окрім цього, необхідно зауважити, що підвищення якості обліково-аналітичного забезпечення як економічної безпеки, так і фінансової стійкості ЗВО повинно здійснюватися винятково в межах Національних положень (стандартів) бухгалтерського обліку державного сектору, Плану рахунків бухгалтерського обліку в державному секторі [2], Закону України «Про вищу освіту» [1] й інших нормативно-правових актів. 
Алгоритм формування обліково-аналітичного забезпечення досліджуваних категорій, виходячи із їх сутності й основних завдань, $\epsilon$ системою контролю за наявністю та рухом бюджетних коштів загального та спеціального фондів, яка будується на загальноприйнятих принципах, виконує управлінську, контрольну й інформаційну функції. Найбільш специфічними та важливими об'єктами (базовими складовими) в обліку ЗВО з метою обліково-аналітичного забезпечення їх економічної безпеки та фінансової стійкості $\epsilon$ доходи, видатки (витрати, затрати) і фінансові результати.

Облік вищезазначених об’єктів є найвідповідальнішим і найскладнішим у контексті обліково-аналітичного забезпечення й потребує найдокладнішої розробки й опрацювання.

3 урахуванням специфіки діяльності ЗВО доцільним є виокремлення субрахунків рахунків 7 (таблиця 1) та 8 (таблиця 2) класів із метою вдосконалення, зокрема деталізації аналітичного обліку джерел фінансового забезпечення функціонування навчальних закладів, витрат і їх оптимізації.

Таблиия 1

Деталізація аналітичних рахунків обліку доходів ЗВО України

\begin{tabular}{|c|c|c|c|c|}
\hline $\begin{array}{c}\text { Номер та } \\
\text { назва рахунку }\end{array}$ & & & & Призначення субрахунку \\
\hline \multirow{3}{*}{70} & \multicolumn{4}{|c|}{ «Доходи за бюджетними асигнуваннями» } \\
\hline & \multirow{2}{*}{701} & \multicolumn{3}{|c|}{ «Бюджетні асигнування розпорядників бюджетних коштів» } \\
\hline & & 7011 & & «Бюджетні асигнування» \\
\hline \multirow{19}{*}{71} & \multicolumn{4}{|c|}{ «Доходи від реалізації продукції (робіт, послуг)» } \\
\hline & \multirow{18}{*}{711} & «До & від реал & ції продукції (робіт, послуг) розпорядників бюджетних коштів» \\
\hline & & \multirow{17}{*}{7111} & & «Доходи від реалізації продукції (робіт, послуг)» \\
\hline & & & 7111.1 & «Структурні підрозділи ЗВО (деканати, кафедри, лабораторії)»* \\
\hline & & & 7111.3 & «Спортивні секиії, змагання» \\
\hline & & & 7111.4 & «Курси вивчення іноземних мов» \\
\hline & & & 7111.5 & «Заочне відділення» \\
\hline & & & 7111.6 & «Контракти з аспірантами та докторантами» \\
\hline & & & 7111.7 & \begin{tabular}{|l|} 
"Додаткові освітні послуги понад затверджене педагогічне на- \\
вантаження (консультаиії, перездачі, комісії)»
\end{tabular} \\
\hline & & & 7111.8 & «Довузівська підготовка» \\
\hline & & & 7111.9 & «Контракт студентів стаціонару» \\
\hline & & & 7111.10 & «Плата за дипломи» \\
\hline & & & 7111.11 & «Послуги комп'ютерних лабораторій» \\
\hline & & & 7111.12 & «Послуги культурно-мистеиъького ичентру» \\
\hline & & & 7111.13 & «Транспортні послуги» \\
\hline & & & 7111.14 & «Послуги видавництвва 3ВО» \\
\hline & & & 7111.15 & «Нічний абонемент у науковій бібліотечі 3ВО» \\
\hline & & & 7111.16 & «Сертифікатні програми» \\
\hline & & & 7111.17 & «Оренда» \\
\hline \multirow[t]{3}{*}{72} & \multicolumn{4}{|r|}{ «Доходи від продажу активів» } \\
\hline & 721 & \multicolumn{3}{|r|}{ «Доходи від продажу розпорядників бюджетних коштів» } \\
\hline & & 7211 & & «Дохід від реалізації активів» \\
\hline \multirow[t]{3}{*}{73} & \multicolumn{4}{|r|}{ «Фінансові доходи» } \\
\hline & 731 & \multicolumn{3}{|r|}{ «Фінансові доходи розпорядників бюджетних коштів» } \\
\hline & & 7311 & & 〈Фінансові доходи розпорядників бюджетних коштів» \\
\hline \multirow[t]{3}{*}{74} & \multicolumn{4}{|c|}{ «Інші доходи за обмінними операціями» } \\
\hline & 741 & \multicolumn{3}{|c|}{ «Інші доходи за обмінними операціями розпорядників бюджетних коштів» } \\
\hline & & 7411 & & «Інші доходи за обмінними операціями» \\
\hline \multirow[t]{3}{*}{75} & \multicolumn{4}{|r|}{ «Доходи за необмінними операціями» } \\
\hline & 751 & \multicolumn{3}{|c|}{ «Доходи за необмінними операціями розпорядників бюджетних коштів» } \\
\hline & & 7511 & & «Доходи за необмінними операціями» \\
\hline
\end{tabular}

Джерело: розроблено автором на основі [2].

*Курсивом: пропозиції автора щодо внесення змін до назв субрахунків. 
Деталізація аналітичних рахунків обліку витрат ЗВО України

\begin{tabular}{|c|c|c|c|c|}
\hline $\begin{array}{l}\text { Номер } \\
\text { i назва } \\
\text { рахунку }\end{array}$ & \multicolumn{4}{|r|}{ Призначення субрахунку } \\
\hline \multirow{6}{*}{80} & \multicolumn{4}{|c|}{ «Витрати виконання бюджетних програм» } \\
\hline & \multirow{5}{*}{801} & \multicolumn{3}{|c|}{ «Витрати розпорядників бюджетних коштів на виконання бюджетних програм» } \\
\hline & & 8011 & \multicolumn{2}{|r|}{ «Витрати на оплату праці» } \\
\hline & & 8012 & \multicolumn{2}{|r|}{ драхування на соціальні заход } \\
\hline & & 8013 & \multicolumn{2}{|r|}{ «Матеріальні витрати» } \\
\hline & & 8014 & \\
\hline \multirow{46}{*}{81} & \multirow{20}{*}{\multicolumn{2}{|c|}{\begin{tabular}{l|l} 
«Витрати на виготовл \\
& $\begin{array}{l}\text { «Витрати } \\
\text { нання ро }\end{array}$
\end{tabular}}} & \multicolumn{2}{|c|}{$\begin{array}{r}\text { «Амортизація» } \\
\text { ня продукщії (надання послуг, виконання робіт)» }\end{array}$} \\
\hline & & & ядників & кетних коштів на виготовлення продукції (надання послуг, вико- \\
\hline & & & & «Витрати на оплату праці» \\
\hline & & & 8111.1 & «Структурні підрозділи ЗВО (деканати, кафедри, лабораторії)»* \\
\hline & & & 8111.2 & «Громадські роботи» \\
\hline & & & 8111.3 & «Спортивні секиії, змагання» \\
\hline & & & 8111.4 & «Курси вивчення іноземних мов» \\
\hline & & & 8111.5 & «Заочне відділення» \\
\hline & & & 8111.6 & «Контракти з аспірантами та докторантами» \\
\hline & & & 8111.7 & $\begin{array}{l}\text { "Додаткові освітні послуги понад затверджене педагогічне } \\
\text { навантаження (консультації, перездачі, комісії)» }\end{array}$ \\
\hline & & & $8111.7 a$ & «Консультаиії з тестування» \\
\hline & & & 8111.8 & «Довузівська підготовка» \\
\hline & & & 8111.9 & «Контракти студентів стаиіонару» \\
\hline & & & 8111.10 & «Витрати на дипломи» \\
\hline & & & 8111.11 & «Послуги комп'ютерних лабораторій» \\
\hline & & & 8111.12 & «Послуги культурно-мистецьккого ичентру» \\
\hline & & & 8111.13 & «Транспортні послуги» \\
\hline & & & 8111.14 & «Послуги видавнищтва ЗВО» \\
\hline & & & 8111.15 & «Нічний абонемент в науковій бібліотеці ЗВО» \\
\hline & & & 8111.16 & «Сертифікатні програми» \\
\hline & & & & «Відрахування на соціальні заходи» \\
\hline & & & 8112.1 & «Структурні підрозділи ЗВО (деканати, кафедри, лабораторії)» \\
\hline & & & 8112.2 & «рромадські роботи» \\
\hline & 811 & & 8112.3 & «Спортивні секиії, змагання» \\
\hline & & & 8112.4 & «Курси вивчення іноземних мов» \\
\hline & & & 8112.5 & «Заочне відділення» \\
\hline & & & 8112.6 & «Контракти з аспірантами та докторантами» \\
\hline & & & 8112.7 & $\begin{array}{l}\text { «Додаткові освітні послуги понад затверджене педагогічне } \\
\text { навантаження (консультації, перездачі, комісії)» }\end{array}$ \\
\hline & & 8112 & $8112.7 a$ & «Консультації з тестування» \\
\hline & & & 8112.8 & «Довузівська підготовка» \\
\hline & & & 8112.9 & «Контракти студентів стаціонару» \\
\hline & & & 8112.10 & «Витрати на дипломи» \\
\hline & & & 8112.11 & «Послуги комп'ютерних лабораторій» \\
\hline & & & 8112.12 & «Послуги культурно-мистецьького иеентру» \\
\hline & & & 8112.13 & «Транспортні послуги» \\
\hline & & & 8112.14 & «Послуги видавничтвва 3ВО» \\
\hline & & & 8112.15 & «Нічний абонемент у науковій бібліотеці 3ВО» \\
\hline & & & 8112.16 & «Сертифікатні програми» \\
\hline & & & & «Матеріальні витрати» \\
\hline & & & 8113.1 & «Структурні підрозділи ЗВО (деканати, кафедри, лабораторії)» \\
\hline & & & 8113.2 & «Громадські роботи» \\
\hline & & & 8113.3 & «Спортивні секиії, змагання» \\
\hline & & 8113 & 8113.4 & «Курси вивчення іноземних мов» \\
\hline & & & 8113.5 & «Заочне відділення» \\
\hline & & & 8113.6 & «Контракти з аспірантами та докторантами» \\
\hline & & & 8113.7 & $\begin{array}{l}\text { «Додаткові освітні послуги понад затверджене педагогічне } \\
\text { навантаження (консультації, перездачі, комісії)» }\end{array}$ \\
\hline
\end{tabular}




\begin{tabular}{|c|c|c|c|c|}
\hline \multirow{39}{*}{81} & \multirow{39}{*}{811} & \multirow{11}{*}{8113} & $8113.7 a$ & «Консультації з тестування» \\
\hline & & & 8113.8 & «Довузівська підготовка» \\
\hline & & & 8113.9 & «Контракти студентів стаичіонару» \\
\hline & & & 8113.10 & «Витрати на дипломи» \\
\hline & & & 8113.11 & «Послуги комп ’ютерних лабораторій» \\
\hline & & & 8113.12 & «Послуги культурно-мистеицького ичентру» \\
\hline & & & 8113.13 & «Транспортні послуги» \\
\hline & & & 8113.14 & «Послуги видавницчтва 3ВО» \\
\hline & & & 8113.15 & «Нічний абонемент у науковій бібліотеиі ЗВО» \\
\hline & & & 8113.16 & «Сертифікатні програми» \\
\hline & & & 8113.17 & «Оренда» \\
\hline & & \multirow{9}{*}{8114} & \multicolumn{2}{|c|}{ «Амортизація» } \\
\hline & & & 8114.1 & «Структурні підрозділи ЗВО (деканати, кафедри, лабораторії)» \\
\hline & & & 8114.2 & «Громадські роботи» \\
\hline & & & 8114.3 & «Спортивні секиії, змагання» \\
\hline & & & 8114.11 & «Послуги комп ’ютерних лабораторій» \\
\hline & & & 8114.12 & «Послуги культурно-мистецьького иеентру» \\
\hline & & & 8114.13 & «Транспортні послуги» \\
\hline & & & 8114.14 & «Послуги видавницетва 3ВО» \\
\hline & & & 8114.17 & «Оренда» \\
\hline & & & \multicolumn{2}{|c|}{ «Інші витрати» } \\
\hline & & \multirow{18}{*}{8115} & 8115.1 & «Структурні підрозділи ЗВО (деканати, кафедри, лабораторії)» \\
\hline & & & 8115.2 & «Громадські роботи» \\
\hline & & & 8115.3 & «Спортивні секиії, змагання» \\
\hline & & & 8115.4 & «Курси вивчення іноземних мов» \\
\hline & & & 8115.5 & «Заочне відділення» \\
\hline & & & 8115.6 & «Контракти з аспірантами та докторантами» \\
\hline & & & 8115.7 & $\begin{array}{l}\text { "Додаткові освітні послуги понад затверджене педагогічне } \\
\text { навантаження (консультації, перездачі, комісії)» }\end{array}$ \\
\hline & & & $8115.7 a$ & «Консультаиії з тестування» \\
\hline & & & 8115.8 & «Довузівська підготовка» \\
\hline & & & 8115.9 & «Контракти студентів стаціонару» \\
\hline & & & 8115.10 & «Витрати на дипломи» \\
\hline & & & 8115.11 & «Послуги комп'ютерних лабораторій» \\
\hline & & & 8115.12 & «Послуги культурно-мистецьького ичентру» \\
\hline & & & 8115.13 & «Транспортні послуги» \\
\hline & & & 8115.14 & «Послуги видавницетва 3ВО» \\
\hline & & & 8115.15 & «Нічний абонемент у науковій бібліотеці 3ВО» \\
\hline & & & 8115.16 & «Сертифікатні програми» \\
\hline & & & 8115.17 & «Оренда» \\
\hline \multicolumn{5}{|l|}{81} \\
\hline \multirow{3}{*}{82} & \multicolumn{4}{|c|}{ «Витрати з продажу активів» } \\
\hline & \multirow{2}{*}{821} & \multicolumn{3}{|c|}{ «Витрати розпорядників бюджетних коштів з продажу активів» } \\
\hline & & 8211 & «Собівартість & даних активів» \\
\hline \multirow{3}{*}{83} & \multicolumn{4}{|r|}{ «Фінансові витрати» } \\
\hline & \multirow{2}{*}{831} & \multicolumn{3}{|c|}{ «Фінансові витрати розпорядників бюджетних коштів» } \\
\hline & & 8311 & «Фінансові вг & И» \\
\hline \multirow{3}{*}{84} & \multicolumn{4}{|c|}{ «Інші витрати за обмінними операціями» } \\
\hline & \multirow{2}{*}{841} & \multicolumn{3}{|c|}{ «Інші витрати за обмінними операціями розпорядників бюджетних коштів» } \\
\hline & & 8411 & «ншші витрати & бмінними операціями» \\
\hline & & & «Ви & I за необмінними операціями» \\
\hline 85 & 851 & «Витрати & необмінними & аціями розпорядників бюджетних коштів» \\
\hline & $8 J 1$ & 8511 & «Витрати за н & гінними операціями» \\
\hline
\end{tabular}

Джерело: розроблено автором на основі [2].

*Курсивом: пропозиції автора щодо внесення змін до назв субрахунків.

На основі результатів аналітичного обліку доходів і витрат 3ВО формують фінансову звітність навчальних закладів, тому саме від точності та своєчасності здійснення обліку всіх видів фінансових надходжень і напрямів їх раціонального, цільового й ефективного використання залежать рівень економічної 
безпеки (високий, середній, низький) та тип фінансової стійкості (абсолютна стійкість, нормальна стійкість, нестійкий фінансовий стан) навчальних закладів (рис.1).

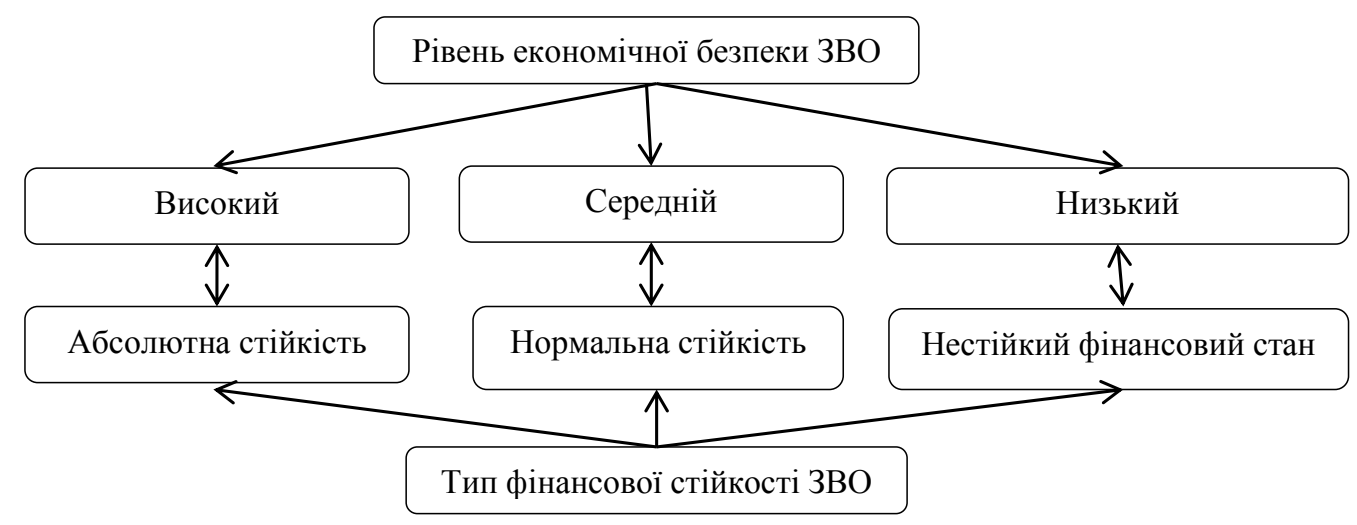

Рис. 1. Взаємозв'язок між рівнем економічної безпеки та типом фінансової стійкості ЗВО

Джерело: розроблено автором.

Щодо фінансових результатів діяльності ЗВО, то вони відображають виконання навчальними закладами покладених на них державою зобов'язань, зокрема надання якісних освітніх послуг. Саме тому в кінці року ЗВО розраховують фінансовий результат за загальним і спеціальним фондами (профіцит «+», дефіцит «-») шляхом відповідного списання всіх доходів (асигнувань і власних надходжень) і видатків (витрат, затрат). Визначені залишки на відповідних рахунках і будуть кінцевим показником діяльності, який впливатиме як на тип фінансової стійкості ЗВО, так і на рівень їхньої економічної безпеки.

Висновки. Отже, уточнивши сутність економічної безпеки та фінансової стійкості ЗВО на ринку освітніх послуг України в контексті їх обліково-аналітичного забезпечення, розкривши особливості взаємозв'язку між ними, можемо виокремити основні напрями підвищення їх рівня шляхом:

- раціонального, ефективного й цільового використання асигнувань із Державного та/або місцевих бюджетів за умови максимального режиму економії всіх можливих ресурсів;

- тісної співпраці ЗВО із роботодавцями як у сфері підвищення якості надання освітніх послуг, забезпечення практичної складової науково-дослідної діяльності, так і можливості фінансування здобуття освіти талановитими, однак малозабезпеченими студентами;

- забезпечення добросовісної конкуренції ЗВО шляхом проведення прозорої, цілеспрямованої профорієнтаційної роботи серед потенційних абітурієнтів, використання новітніх інноваційних технології у навчально-науковому та навчально-виховному процесі, залучення професорсько-викладацького складу та студентів до участі в міжнародних обмінних програмах і грандах;

- використання поглибленої аналітики за рахунками обліку доходів (асигнувань із Державного та/ або місцевих бюджетів України, власних надходжень, зокрема завдяки фандрайзингу) і видатків (витрат, затрат).

Упровадження зазначених вище пропозицій сприятиме проведенню ефективних аналітичних $\mathrm{i}$ контрольних процедур за результатами освітньої й неосвітньої діяльності ЗВО в розрізі використання бюджетних асигнувань і власних коштів, що загалом дозволить підвищити якість обліково-аналітичного забезпечення їх економічної безпеки та фінансової стійкості в умовах реформування сфери вищої освіти України.

\section{Література:}

1. Про вищу освіту: Закон України від 01.07.2014 № 1556-VII. URL: http://zakon.rada.gov.ua/laws/show/155618 (дата звернення 28.08.2018).

2. Про затвердження Плану рахунків бухгалтерського обліку в державному секторі: Наказ Міністерства фінансів України від 31.12.2013 р. №1203. URL: http://zakon4.rada.gov.ua/laws/show/z0161-14 (дата звернення 28.08.2018).

3. Національна стратегія розвитку освіти в Україні на 2012 - 2021 роки. Схвалена Указом Президента України № 344/2013 від 25 червня 2013 року. URL: http://zakon.rada.gov.ua/laws/show/344/2013\#n10 (дата звернення 27.08.2018).

4. Стратегія реформування вищої освіти в Україні до 2020 року. URL: file://C:/Users/\%D0\%90\%D0\%B4\%D 0\%BC\%D0\%B8\%D0\%BD\%D0\%B8\%D1\%81\%D1\%82\%D1\%80\%D0\%B0\%D1\%82\%D0\%BE\%D1\%80/Downloa ds/502ce9ae970f16d556a38b1e26dc78a4.pdf. 
5. Стратегія інноваційного розвитку України на 2010 - 2020 роки в умовах глобалізаційних викликів. URL: http:// kno.rada.gov.ua /uploads/ documents/36380.pdf.

6. Середньостроковий план пріоритетних дій Уряду до 2020 року : затверджено розпорядженням Кабінету Міністрів України від 03.04.2017 № 275-p. URL: http://www.kmu.gov.ua/control/uk/cardnpd?docid=249935442 (дата звернення 28.08.2018).

7. Дорожня карта освітньої реформи (2015-2025) / Міністерство освіти і науки України. URL: http:// mon. gov.ua /content /Діяльність/ Зв'язки\%203\%20громадськістю/Громадське\%20обговорення/08-road-map-sk-end. pdf.

8. Стратегія реформування системи управління державними фінансами на 2017-2020 роки : схвалено розпорядженням Кабінету Міністрів України від 08.02.2017 № 142-p. URL: http://www.kmu.gov.ua/control/uk/ cardnpd?docid=249797370. (дата звернення 30.08.2018).

9. Стеців І.С. Економічна безпека ВНЗ: сутність та особливості планування. Наиіональний університет «Львівська політехніка». 2010. С. 218-222.

10. Тюлєнєв Г.Д. Оцінювання економічної безпеки вищих навчальних закладів в Україні. URL: http:// thesis.at.ua/ publ/15_11_15_12_2013_r_ menedzhment_rozvitok_teorija_ta_praktika/tjulenev_g_d_ocinjuvannja ekonomichnoji_bezpeki_vishhikh_navchalnikh_zakladiv_v_ukrajini//9-1-0- $27 \overline{0}$.

11. Харчук Ю.Ю. Обліково-аналітичне забезпечення фінансової стійкості вищих навчальних закладів державної та комунальної власності : дис. канд. економічних наук : 08.00 .09 «Бухгалтерський облік, аналіз і аудит» / Харчук Юлія Юріївна. - Київ, 2014. - 208 с.

12. IPSAS 1 «Presentation of Financial Statements». Handbook of International Public SectorAccounting Pronouncements. 2014, Vol. I. URL: http://www.ifrs.org.ua/wp-content/uploads/2014/11/Handbook-of-InternationalPublic-Sector-Accounting-Pronouncements-Volume-1.pdf. 